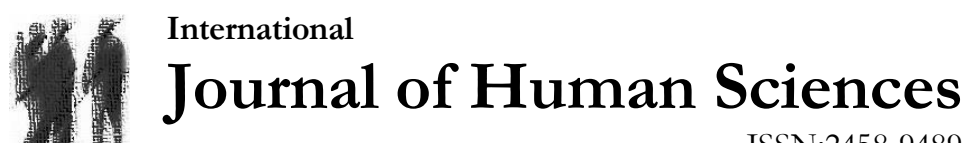 \\ ISSN:2458-9489
}

Volume 16 Issue 2 Year: 2019

\section{Symbiotic relationship between university and the city: the case of Alaeddin Keykubat Campus of Selçuk University- Konya}

\author{
Yavuz Arat ${ }^{1}$ \\ Mehmet Uysal ${ }^{2}$
}

\begin{abstract}
The university establishment process in Konya started in the 1950s for the first time. After 1960s, the institutions giving higher education in the city came into activity, and in 1976 Selçuk University was established. Selçuk University, since its establishment, has lead the single-centered city to develop towards the north, and at the same time, also the campus as a center of attraction has caused a shift of the population concentration to the region. The university, which makes good use of the city's potentials in the change of the city form, also made it possible to create surplus values by using the values that the city has in the fields of agriculture, agriculture industry, and technology. The Selçuk University Alâeddin Keykubat Campus is still a potential force that creates economic surplus, attracts population and shapes the city.
\end{abstract}

Keywords: Selçuk university; campus; Konya city; symbiotic relationship.

\section{Introduction}

As a living organism, cities undergo morphological changes in terms of the functions they undertake in the process. Agriculture, industry, tourism, education or other factors can be influential in this formal change of the settlements. As a potential power of the 20th century, university campuses are also considered to have important influences in the formation of cities. This situation reflects the change and transformation as a result of the symbiotic relationship of urban and campus settlement duality.

Konya has been a settlement with its own urban dynamics due to its geographical location in the center of Anatolia, being the capital of Anatolian Seljuk Empire, the state capital in the Ottoman period, and an important industrial center during the republic period. It can be asserted that the city, which has a unique formation in terms of cultural, social and physical sense, has developed in the form of a single centered / focused drop around the mound of Alâeddin Hill until the 1950s.

The university establishment process in Konya started in the 1950s for the first time. After 1960s, the institutions giving higher education in the city came into activity, and in 1976 Selçuk University was established. Selçuk University, since its establishment, has lead the single-centered city to develop towards the north, and at the same time, also the campus as a center of attraction

\footnotetext{
${ }^{1}$ Assoc. Prof. Dr., Necmettin Erbakan University, Department of Architecture, yavuzarat@gmail.com

2 Prof. Dr., Necmettin Erbakan University, Department of Architecture, mimuysal@gmail.com
} 
Arat, Y., \& Uysal, M. (2019). Symbiotic relationship between university and the city: the case of Alaeddin Keykubat Campus of Selçuk University-Konya. Journal of Human Sciences, 16(2), 582-589. doi:10.14687/jhs.v16i2.5500

has caused a shift of the population concentration to the Konya city and its hinterland. The university contributes convenient use of the urban potentials and dynamics in the changing process of the urban form, also makes it possible to create surplus values by using the values that the city has in the fields of agriculture, agricultural industry, and technology. It can be said that the Selçuk University Alâeddin Keykubat Campus is still a potential force that creates economic surplus, attracts population and shapes the city.

The aim of this study is to reveal the site selection and development of the campus and its effects on the close fabric and urban formation in the context of university-city relation. In this study, a method is followed depending on visual sources such as development plans, air photographs, development plan reports, studies with theoretical knowledge and also surveyingobservations works. Afterwards, the symbiotic relationship between Selçuk University and Konya city is systematically analyzed.

\section{Konya: A City Profile}

The first city development (reconstruction) plan of Konya was designed by Asim Kömürcüoğlu in 1944 and population census of the city in the same year was taken as 58000 (Kömürcüoğlu 1946). In this first urban planning period, the city was predicted to develop as historic center-oriented and westward (railway-station) in accordance with the single-centered compact city model (Yenice 2005, 52). As a result of the housing needs, the second development plan of Konya was designed by Ferzan Baydar and Leyla Baydar (Baydar and Baydar 1954). Despite its single-centred westward development projection, the 1966 Haluk Berksan and Yavuz Taşc1 development plan selected through a competition was prepared for a city that spread out southward and looked like a settlement scattered on the radiative roads. Although this plan has projected that the university area would be located on the east side of the railway, this area was converted into housing zones in the process.

In 1974, Haluk Berksan and Yavuz Taşc1 made additional plans for the organized industrial and 4th slum prevention zones (Yenice 2005, 58-68). The city development has been directed to the west and north because of the agricultural lands and industrial areas located in the south and east sides of the city. A linear settlement to the north is observed to take place in this plan instead of a single centred compact settlement (Yenice 2005, 70). In 1975, Yavuz Taşc1 carried out the 1983 environmental plan due to extension of the urban area and incapability of the development plan to meet the city needs (Taşç1 1983). The most important decision that was unplanned but influenced the city in this period was the site selection of the university (Selçuk University Alâeddin Keykubat Campus) in 1979. Due to this decision, a location on the Istanbul road (north of the city) and about $20 \mathrm{~km}$ away from the city center was chosen for the university site. In the context of this decision, in order to prevent uncontrolled and unplanned developments, housing districts along the axis to the university have been planned parallel to Istanbul road, thus the development plan returned to compact and linear urban model (Yenice 2005, 75-78). The northern linearity spread to the north east side through the areas zoned for construction, and the air pollution and industry development in the city required the Yavuz Taşc1 1999 Konya master development plan, and then for this plan the target population census for 2020 was determined as 1800000 (Figure 3). The Selçuk University was targeted to have three major sub-centers, namely Alaeddin Keykubat Campus, Tömek (north east) and north centre (Taşç1 1999). As a result of the addition of transportation system (light rail system), the area across to the Selçuk University Alâeddin Keykubat Campus (northeast) and located in the north side of the city was determined as the development area of the city (Yenice 2005, 87). 
Arat, Y., \& Uysal, M. (2019). Symbiotic relationship between university and the city: the case of Alaeddin Keykubat Campus of Selçuk University-Konya. Journal of Human Sciences, 16(2), 582-589. doi:10.14687/jhs.v16i2.5500

\section{Selçuk University: Spatial and Organizational Context}

The university establishment process in Konya started in the 1950s for the first time. After 1960s, the institutions giving higher education in the city came into activity, and in 1976 Selçuk University was established. Selçuk University, which started its education life with two faculties in 1976-1977 academic year, did not develop until 1982, so only a limited number of students [400 students] got educated in its various establishments within the city. In 1982, its capacity has reached to 8 faculties, 4 colleges and 3 institutes and the number of students has increased accordingly. Nowadays, Selçuk University provides education and training to approximately 5000 students in Alâeddin Keykubat Campus with 17 faculties, 1 conservatory, 6 institutes, 12 colleges and 2 vocational colleges (Selçuk University, 2017).

After the foundation of Selçuk University in 1975, several lands from various regions in Konya was investigated, and then the land of 9200 decares belonging to Turkish Treasure within the boundaries of Ardiçlı Village, which is about $20 \mathrm{~km}$ to the north of the city, was selected as the campus territory, although it was not suitable in terms of soil, infrastructure and transportation (Semiz 1999) (Figure 1). An additional 6200 decares of land were added to this campus area in 1997 (Büyükşahin Sıramkaya 2005, 58; Kuyrukçu 2011, 49). The design of the campus was given to the TEKSIS group in 1980 and "Campus Planning and Programming Research" was prepared. This research has investigated future situation of the campus and its relation with the city, and collected the relevant data. As a result of this report, construction of the university with 5 faculties was planned and its academic units, social facilities, accommodation units, central administrative units and a capacity of 10,000 students were projected to be built until 2000 (TEKSIS 1980).

\section{Symbiotic Relationship: Selçuk University and Konya City}

Selçuk University has an important place in the Konya economy in terms of income and employment due to a large number of students it has and also its educational and administrative staff. The student expenditures offer both investment and urban development as well as employment opportunities (Görkemli 2005, 139). Görkemli (2005) determined that there were 41524 students at Selçuk University's Alâeddin Keykubat Campus and the expenses of these students mainly included food and accommodation. This accommodation has been met mostly in the campus and also in the Bosnia-Herzegovina neighborhood located near the campus (Görkemli 2005, 131). Korkut (2011) states that before the 1980s Turkey, the relation between a city and the universities established outside of that city was influenced by the fact that the social areas on campus and the dormitories that provide shelter has spread out to both campus and city. In this context, it is seen that Selçuk University is both an attraction point of the city and effective in the expansion of the city towards the university (Korkut 2011, 125-126) (Figure 2).

The Bosnia-Herzegovina Quarter with a population of 40,000 today, located in the east of the Selçuk University Alâeddin Keykubat Campus and planned as a slum prevention zone, has been the living space of the students in the process. Students in this center prefer this area that is located in the campus neighborhood, for both campus facilities (sports, culture, etc.) as well as ease of access to the university. Selçuk University Alâeddin Keykubat Campus is the biggest influence on the Konya city's northward linear expansion. The university, which was chosen as an unplanned site in 1979, became the most important sub-center in the city and required additional transportation investments (light rail system) due to population density and mobility. In addition to this, the university also had unplanned developments in its own settlement, it had to solve the intra-campus transportation problem because the university was shaped beyond the pedestrian scale, so a light rail system was integrated into the settlement. This situation has distorted the intra-campus transport hierarchy and setting. It is normal for this formal deterioration to occur in the campus, which contains threefold of the 5000 students and 3 faculties planned in 1980. In this context, this situation has reflected firstly on neighborhood settlement then the urban settlement. 
Arat, Y., \& Uysal, M. (2019). Symbiotic relationship between university and the city: the case of Alaeddin Keykubat Campus of Selçuk University-Konya. Journal of Human Sciences, 16(2), 582-589. doi:10.14687/jhs.v16i2.5500

\section{Results}

As a result of this study, it is stated that Selçuk University since 1995 to nowadays has played an important role in the spatial and functional development process of Konya city. In this framework, it can be said that the University as a socio-cultural focal point leads to direction of the development of Konya city. Especially, the locational position of the university effects on the development of housing areas and public transport system in the city.

Also, the university as an academic and scientific complex including institutes of social and natural sciences, research centers and also techno park, contributes to the development of brand values of Konya city in technological and innovational context. These findings are indicated that the symbiotic relationship between Selçuk University and Konya city has continued in both spatialfunctional and also socio-cultural interaction. 
Arat, Y., \& Uysal, M. (2019). Symbiotic relationship between university and the city: the case of Alaeddin Keykubat Campus of Selçuk University-Konya. Journal of Human Sciences, 16(2), 582-589. doi:10.14687/jhs.v16i2.5500

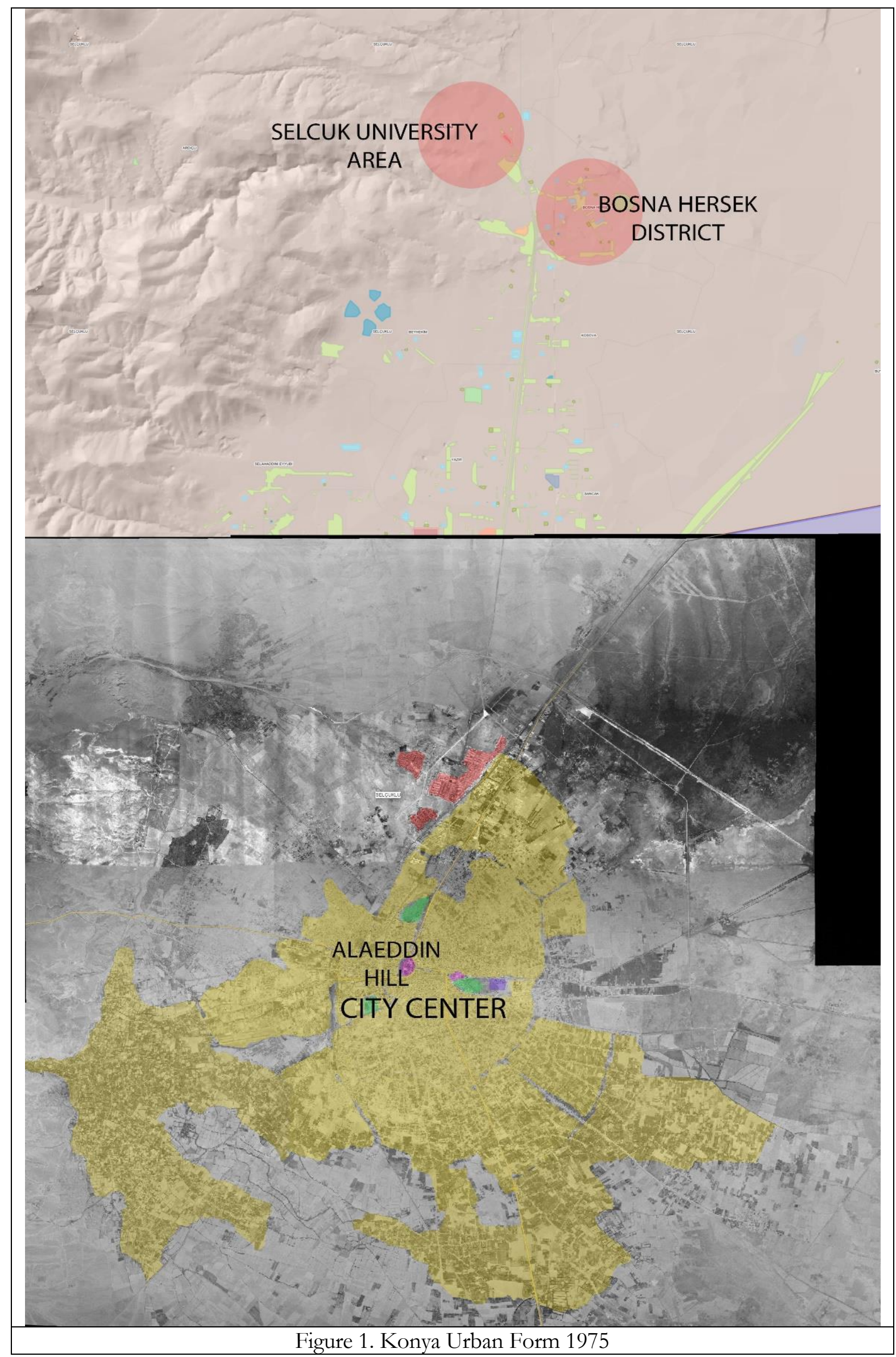


Arat, Y., \& Uysal, M. (2019). Symbiotic relationship between university and the city: the case of Alaeddin Keykubat Campus of Selçuk University-Konya. Journal of Human Sciences, 16(2), 582-589. doi:10.14687/jhs.v16i2.5500

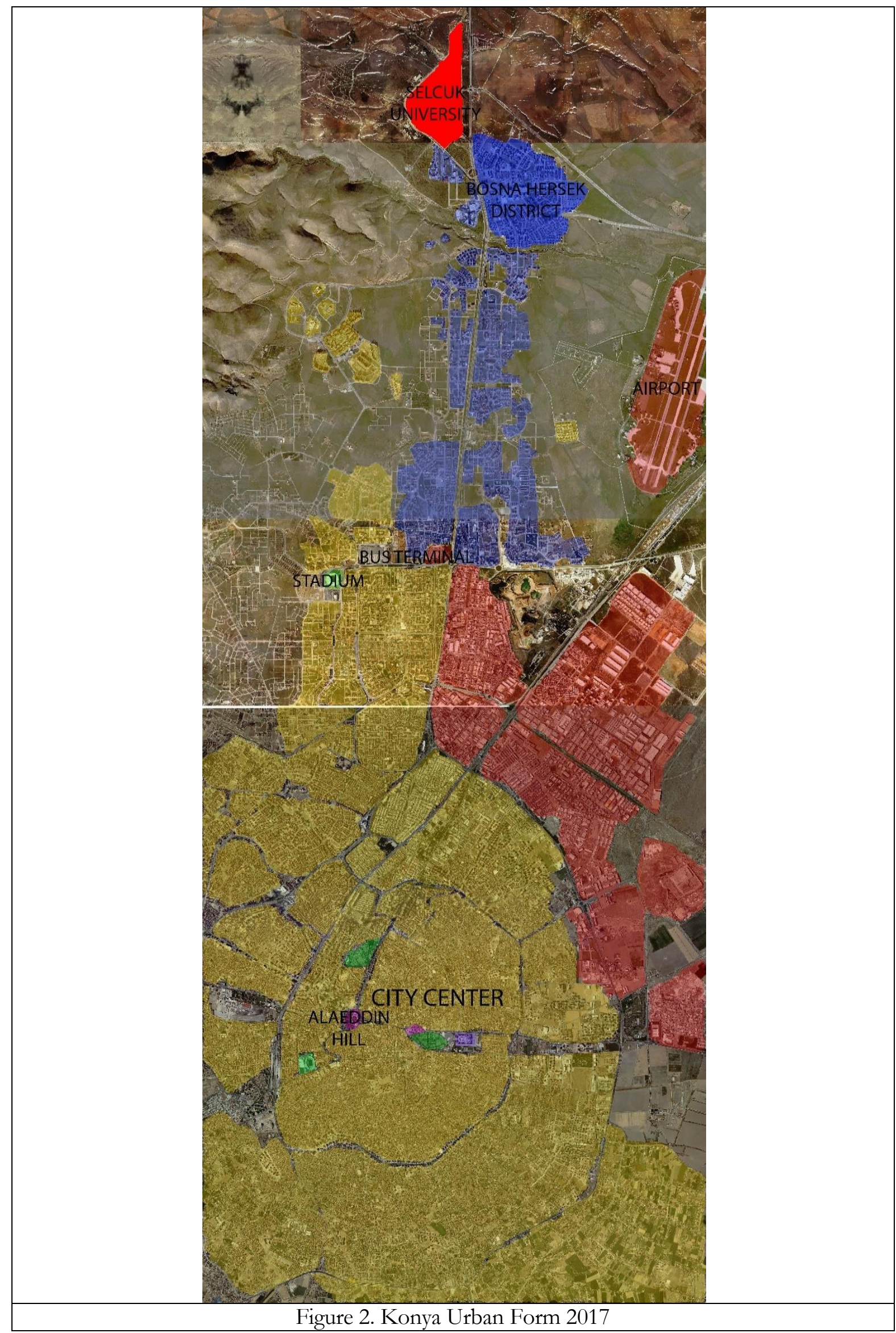


Arat, Y., \& Uysal, M. (2019). Symbiotic relationship between university and the city: the case of Alaeddin Keykubat Campus of Selçuk University-Konya. Journal of Human Sciences, 16(2), 582-589. doi:10.14687/jhs.v16i2.5500

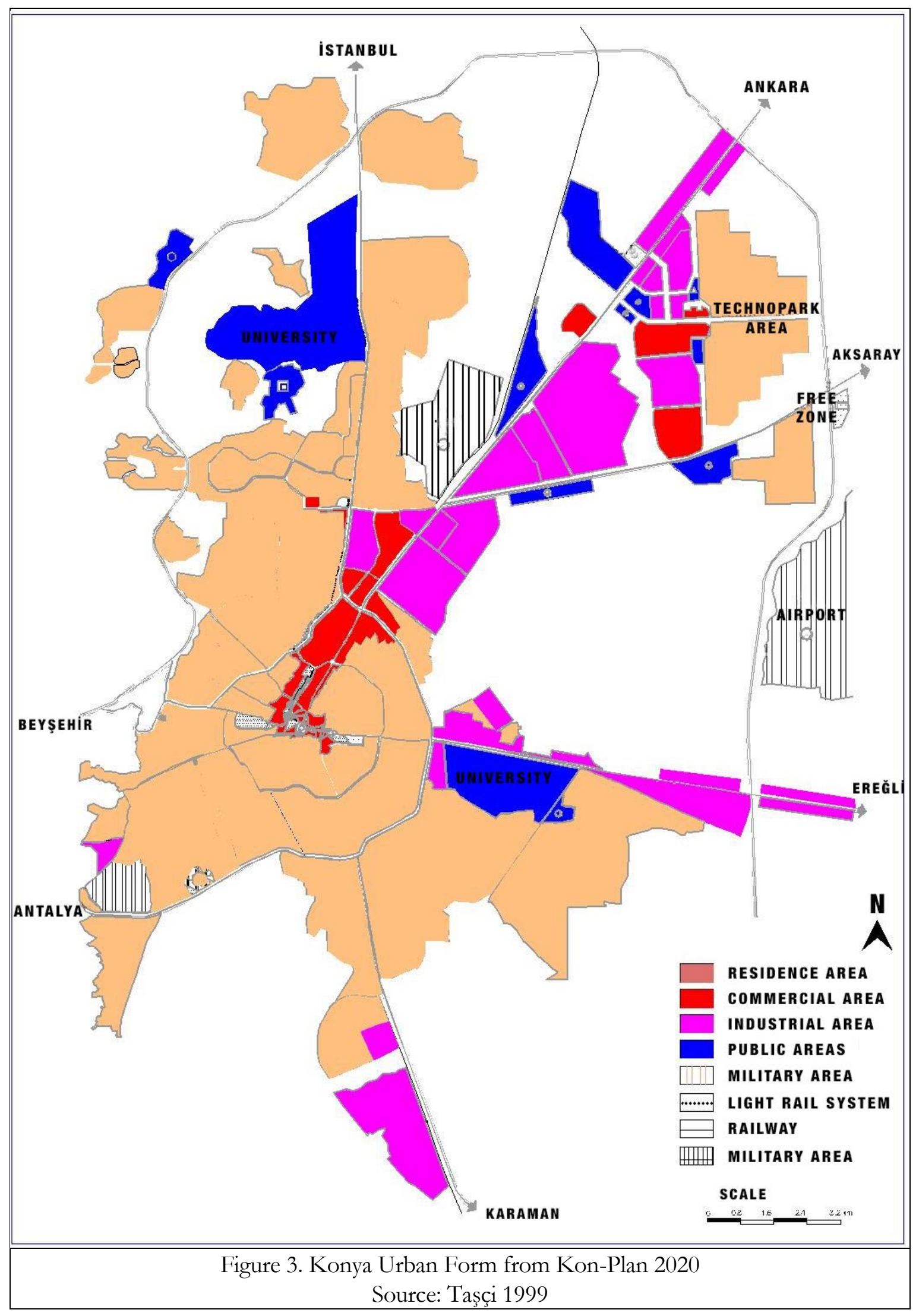


Arat, Y., \& Uysal, M. (2019). Symbiotic relationship between university and the city: the case of Alaeddin Keykubat Campus of Selçuk University-Konya. Journal of Human Sciences, 16(2), 582-589. doi:10.14687/jhs.v16i2.5500

\section{References}

Baydar F. \& Baydar L. (1954). Konya Development Plan Report, Ankara.

Büyükşahin Sıramkaya S., (2005). University Campus Settlements and Spaces for Common Use, Selçuk University Graduate School of Natural Applied Sciences Department of Architecture, Unpublished Master Thesis, Konya.

Görkemli H. N. (2005). The Impact of Selçuk University on the Economy of Konya, Selçuk University Graduate School of Natural Applied Sciences Department of City and Regional Planning Unpublished Master Thesis, Konya.

Korkut G. (2011). City Effect on Shaping the University Campus' Space Organization, İstanbul Technical University Graduate School of Natural Applied Sciences Department of Architecture Unpublished Master Thesis, İstanbul.

Kömürcüoğlu A. (1946). Konya Development Plan Report, Ankara 1946.

Kuyrukçu Z. (2012). A Research on Physical Changes in the Campuses; Example of Alâeddin Keykubat Campus of Selçuk University, Graduate School of Natural Applied Sciences, Department of Architecture Unpublished Master Thesis, Konya.

Selçuk University (accessed 06.06.2017). Selçuk University, < http://www.selcuk.edu.tr/>.

Semiz Y. (1999) "History of Selçuk University ", From Past to Today Konya' Cultural Background and Selçuk University, Selçuk University Press Konya, 321-400.

Taşc1 Y. (1983). Konya 2000 Strategic Spatial Plan' Report, Ankara.

Taşc Y. (1999). Konya 2020 Master Revision Plan’ Report, Ankara.

Teksis (1980). Selçuk University Planning and Programming Report, Ankara 1980.

Yenice M. S. (2005), A Study on The Development of Urban Form in Planning Process; The Case of Konya, Selçuk University Graduate School of Natural Applied Sciences Department of City and Regional Planning Unpublished Master Thesis, Konya. 